Paedagogia Christiana

I/27 (201 I) - ISSN 1505-6872

Eugeniusz Sakowicz*

Warszawa

\title{
Wychowanie młodego pokolenia w religii biblijnego Izraela
}

Biblia Hebrajska jest świętą księgą Żydów ukazującą dzieje tego narodu, wybranego przez Boga, do spełnienia przezeń misji o zasięgu uniwersalnym. To, co w Biblii odnosi się wprost i bezpośrednio do Żydów, może i powinno - z perspektywy czasu - być odnoszone również do innych narodów. Wybranie przez Boga jednego narodu nie oznaczało „niewybrania” innych.

Wśród rozlicznych tematów podejmowanych w Piśmie Świętym na szczególną uwagę zasługuje wychowanie i kształcenie młodego pokolenia. I chociaż Biblia Hebrajska nie jest traktatem pedagogicznym, to jednak zawiera szereg uwag, aluzji oraz refleksji dotyczących interesującego nas problemu. To, co święta Księga Żydów mówi o wychowaniu i kształceniu młodego pokolenia, można i trzeba odnieść do pedagogiki narodów nieżydowskich, w tym - chrześcijan ${ }^{1}$.

Wgłębiając się w wypowiedzi Księgi (posiadającej walor objawionego Pisma) dotyczące procesu wychowania i kształcenia dzieci i młodzieży, ale też i dorosłych, należy odpowiedzieć na następujące pytania: Jak przebiegała edukacja i uczenie się?; Co było przedmiotem nauczania?; Kto był odpowiedzialny za nauczanie i edukację?; Kim byli „uczący się”?; Gdzie (w ja-

* Prof. zw. dr hab. Eugeniusz Sakowicz, kierownik Katedry Pedagogiki Kultury i Edukacji Międzykulturowej, Wydział Nauk Pedagogicznych, Uniwersytet Kardynała Stefana Wyszyńskiego w Warszawie.

${ }^{1}$ Zob. J. Bagrowicz, Wychowanie w świetle Biblii, w: A. Rynio (red.), Wychowanie chrześcijańskie. Między tradycja w wspótczesnościq, Lublin 2007, s. 39-60; W. Chrostowski, Wychowanie i kształcenie młodego pokolenia w przedwygnaniowym Izraelu, w: tenże, Asyryjska diaspora Izraelitów i inne studia, Warszawa 2003, s. 151-168. 
kich okolicznościach) odbywała się edukacja? Pytania te dotyczą następujących zagadnień: metodyki nauczania, przedmiotów nauczania, nauczycieli, uczniów oraz szkoły².

„Dziś” judaizmu oraz „dziś” chrześcijaństwa ma swoje początki w religii biblijnego Izraela. I chociaż jedna Księga Biblii składa się z licznych „Ksiag", to charakteryzuje się jednorodnością. Pozwala to liczne „zwoje” świętych tekstów traktować jako zwartą całość. To, co stanowi o jedności Biblii Hebrajskiej, charakteryzuje również naród Hebrajczyków. Są oni ludem ukształtowanym, uformowanym przez Biblię, stanowią „lud Księgi”. Celebrują Księgę, która ukształtowała ich tożsamość.

\section{Monoteizm, świętość, moralność i wolność ludzkiej woli}

Najważniejszą przedstawioną przez natchnionych autorów Biblii ideą jest monoteizm. Bóg jedyny miał być jedynym Panem Żydów. Drugą cecha, wiążącą się z monoteizmem, będącą oczywistą konsekwencją wiary $\mathrm{w}$ jednego Boga, jest świętość Izraela. Żydzi nie uczynili siebie samych świętymi. Źródłem świętości jest Bóg, który wybrał Izraela, czyniąc z niego „naród święty - wybrany". Izrael winien wobec tego postępować adekwatnie do tożsamości jemu darowanej ${ }^{3}$.

Konsekwencją, niejako „wypadkową” monoteizmu i świętości jest moralność. Stanowi ona trzecią cechę wyróżniającą Izraela. O moralności w licznych miejscach wypowiada się Biblia, podając nie tylko teoretyczne rozważania, ale „ilustrując” jej występowanie bądź brak. Święta Księga wskazuje na losy poszczególnych postaci, od wielkich nauczycieli i mędrców narodu poczynając, na zwykłych, prostych ludziach kończąc. Z Biblii wypływa oczywisty wniosek - postępowanie Hebrajczyków nie może być motywowane złem, nie może oznaczać wyboru i trwania w grzechu. Żydzi mają być prawi (czyli właśnie moralni) w relacji z Bogiem i między sobą. Uczyć się tego powinni od początku swojego życia. Żydowskie życie to szkoła moralności.

Kolejną ideą wyraźnie obecną w Biblii jest szacunek dla wolnej woli człowieka. On sam może wybierać własną drogę życia. Bóg Wszechmogą-

2 Zob. syntetyczną odpowiedź na te pytania: E. Sakowicz, Wychowanie w religiach świata, w: C. Rogowski (red.), Leksykon pedagogiki religii, Warszawa 2007, s. 883-889. W artykule tym oprócz wychowania w judaizmie omówione zostało wychowanie w: hinduizmie (s. 876-880), konfucjanizmie (s. 880-883) oraz islamie (s. 889-891). Zob. spis literatury z zakresu wychowania w judaizmie, tamże, s. $888 \mathrm{n}$.

${ }^{3}$ H. R. G. Fried, Education in the Bible, the Talmud, and the Prayer Book, Stanford 1981, s. 3. 
cy - Pan całego Izraela i poszczególnego Żyda nigdy nie kieruje się taktyką zniewalania kogokolwiek. Człowiek dokonuje własnego wyboru podejmując równocześnie jego konsekwencje, również złe, jeśli wybór służył złu. Bóg natomiast zawsze przekonuje Swój naród i człowieka, iż każde ludzkie życie ma wartość, a zatem i sens.

Najistotniejszą w ,strategii” Jedynego Boga - Jahwe wobec Izraelitów była miłość. To właśnie z tej Bożej miłości, będącej afirmacją całego narodu przez Stwórcę, wynikają reguły wychowania w religii biblijnego Izraela.

Wskazane wyżej „wspólne mianowniki” Biblii (i całego Izraela, jako narodu „wyrastającego” z tej Księgi) stanowią rdzeń nauczania biblijnego.

\section{Słownictwo biblijne związane z dziełem wychowania}

Biblia kładzie duży nacisk na edukację. Nie ma jednak w niej fragmentów systematycznie prezentujących filozofię i teologię wychowania narodu żydowskiego. Księgą która może odgrywać kluczową rolę dzieła dydaktycznego, jest bezsprzecznie Księga Przysłów ${ }^{4}$.

W Biblii występuje szereg terminów, które określały proces nauczania i uczenia się. Do kwestii edukacji odnoszą się m.in. następujące określenia: „,instruowanie”, ,przestrzeganie”, „trenowanie”, „,nakazywanie”, ,oznajmianie”, „prowadzenie”. Żydzi uważaja, iż cała Biblia może być postrzegana jako księga dydaktyczna, chociaż formalnie nią nie jest.

Terminami, które powtarzają się najczęściej w Biblii oraz w innych źródłach hebrajskich, a które dotyczą wychowania i kształcenia (czyli w ogóle pedagogiki), są zarówno czasowniki, jak i rzeczowniki: yārāh, yāsar, lāmad, hebîn i inne. Czasownik yārāh (od rdzenia yrh) oznacza „rzucać, wyciagnąć, pokazać”; w formie hifil (hôrāh) odpowiada „wskazywaniu”, ,pokazywaniu”, „wskazywaniu kierunku”, „nauczaniu”, „kształceniu”. Rzeczownik to torāh, czyli „kształcenie”, „nauczanie”, „,kierunek”. Termin ten Septuaginta tłumaczy zazwyczaj jako nómos („Prawo”). W praktyce pojęcie to wskazuje na zespół norm, których przestrzeganie pozwala danemu człowiekowi bądź grupie ludzi dobrze żyć. Pochodna mōreh (w liczbie mnogiej mōrîm) wskazuje na „tego, który kształci”, „który naucza”, jednym słowem - „nauczyciela”. Kształcić, formować to, według języka hebrajskiego, „wpajać nauki i zachowania sugerowane przez Prawo" (Torę) $)^{5}$.

${ }^{4}$ Zob. J. Kręciło, Portret mędrca w Księdze Przystów 1, 1-7, „Collectanea Theologica” 76 (2006), nr 1, s. 5-25; tenże, Portrayal of the Wise Man in the Book of Proverbs 1, 1-7, „The Polish Journal of Biblical Research" 5 (2006), nr 1, s. 29-48.

${ }^{5}$ F. Gioia, Metodi e ideali educativi dell'Antico Israele e del Vicini Oriente, Città del Vaticano 2008, s. 152. Zob. też S. Jankowski, Wychowanie w Starym Testamencie w świetle 
Czasownikiem o najbardziej „pedagogicznym wymiarze” jest yāsar. Słowo to thumaczy się następująco: „kształtować”, „,formować”, ,wychowywać”, „,napominać”, „karcić”, „karać”. Rzeczownik pochodzący od powyższego czasownika oznacza „nauczanie”, „kształcenie”, ale również „,naganę”, „upomnienie”, „dyscyplinę”. Greckim odpowiednikiem jest paideuō, czyli „wychowywać”, od którego pochodzą terminy: paidei - „wychowanie” oraz pais „dziecko”. Bardziej ogólnym czasownikiem odnoszącym się do wychowania jest lāmad (od rdzenia lmd), który oznacza „ćwiczyć”, „ujarzmić”, „medytować”, „uczyć się”, „studiować”. W formie piel znaczy natomiast „kształcić”, „nauczać”. Wyrazami pochodnymi od wyrazu podstawowego są: mĕlāmmed (w liczbie mnogiej mĕlammūdîm), czyli „ten, który naucza”, tj. „nauczyciel” oraz limmūd lub tālmūd - „ten, który jest uczony”, czyli uczeń, i wreszcie - Tālmūd, tj. „,nauka"6.

Inne terminy posiadają szersze znaczenie, chociaż stosowane są także w edukacji. Są nimi: hebîn (hifil od bîn) - „dać do zrozumienia”, „nauczać” oraz bānîm - „uczeń”. Bogata terminologia hebrajska potwierdza, że edukacja była wśród Żydów ważnym problemem.

\section{Wychowanie rodzinne}

Według Biblii, pierwszą szkołą jest dom rodzinny. Pogłębianie wiary w zaciszu rodzinnym należało do codziennych praktyk Żydów epoki biblijnej. Ojciec powinien był nauczać swoje dzieci Słowa Bożego podczas rozmaitych codziennych zajęć i prac (Pwt 6). Dziecko uczyło się poprzez samo uczestnictwo w religijnych uroczystościach, jak również przez naśladowanie dorosłych. Kształcenie dzieci, według Biblii, odbywało się nie tylko w domu, ale i w szerszej wspólnocie ${ }^{7}$.

Biblia ukazuje dzieci jako dar Boga ${ }^{8}$. Dzieci „otoczone” i obdarzone miłością swoich rodziców wprowadzane są w „klimat” edukacji, którym jest ro-

terminologii, w: J. Bagrowicz, S. Jankowski, „Pan Bóg twój, wychowuje ciebie” (Pwt 8, 5). Studia z pedagogii biblijnej, Torun 2005, s. 29-45 (zob. spis literatury z zakresu pedagogii biblijnej w ogóle - Bibliografia, tamże, s. 225-232).

${ }^{6}$ F. Gioia, dz. cyt., s. 152.

${ }^{7}$ Więcej na temat dziecka i jego wychowania w Starym Testamencie zob. J. Bagrowicz, Wychowawcza opieka nad dzieckiem w tradycji biblijnej Starego Przymierza, w: B. Smolińska-Theiss (red.), Pokój z dziećmi, Warszawa 1999, s. 28-40; zob. też: tenże, Wychowanie w świetle Biblii, s. 52-54; tenże, Pedagogia Przymierza (II). Założenie pedagogii rodziny w świetle Biblii, „Paedagogia Christiana” 3 (1999), s. 5-23.

${ }^{8}$ Zob. E. Sakowicz, Dziecko w judaizmie (1). Biblia o dziecku, „Słowo Żydowskie” 14-15 (1994), s. 16; tenże, Dziecko w judaizmie (2), Okres potalmudyczny, „Słowo Żydowskie" 18 (1994), s. 14. 
dzicielskie oddanie i poświęcenie się. Biblia wskazuje na dom rodzinny jako swoistą ,instytucję" wychowania, jako jedyną w swoim rodzaju „szkołę”. Nie mówi natomiast o jakimś zinstytucjonalizowanym wychowywaniu dzieci. Nawet jeśli jest mowa o nauczycielach, którym rodzice powierzyli dzieło wychowywania ich dzieci, to nie działali oni w ramach jakichś „sztywno” zorganizowanych instytucji edukacyjnych.

Edukacja w czasach biblijnych miała charakter nieformalny, a prawdziwą szkołą był dom rodzinny. To właśnie w domu od momentu karmienia dziecka piersią winien zacząć się proces jego edukacji. W rodzinie miejsce uprzywilejowane zajmował syn pierworodny. Przez całe lata był on wychowywany, przygotowywany do podjęcia zadań jako sukcesor ojca.

Aż do czasu niewoli babilońskiej w VI wieku przed Chrystusem brak było w języku hebrajskim oddzielnego słowa na określenie szkoły. Szkołą wciąż pozostawał dom rodzinny. Pojęcie ,szkoła” pojawiło się po deportacji babilońskiej. Dopiero w późniejszym czasie zaczęto zakładać szkoły. Jednymi z pierwszych były „szkoły prorockie”, które jednak nie przypominały formalnych szkół. Żadna z wybitnych postaci biblijnych nie została ukazana w świętej księdze Żydów jako ta, która zdobyła formalne wykształcenie. Przez cały czas Starego Testamentu szkołami były domy rodzinne, a nauczycielami - rodzice, przede wszystkim ojciec.

W religii biblijnego Izraela rodzina stanowiła podstawową jednostkę społeczno-ekonomiczną. W niej podejmowało się i rozwiązywało problemy jej członków, w tym również te, które dotyczyły edukacji młodych. Żydowski dom rodzinny, rozumiany jako szkoła, był najstarszym miejscem formowania się charakteru dziecka. Pierwszymi opiekunami byli rodzice, szczególnie ojciec. Rodzina była u Żydów czasów biblijnych i jest po dzień dzisiejszy „gniazdem”, w którym dziecko przychodzi na świat, miejscem, w którym uczy się stawiać i stawia swoje pierwsze kroki. W domu uczy się ono mówić i - co więcej - uczy się żyć. W domu dziecko nawiązuje pierwsze kontakty z otaczającą rzeczywistością. Poznaje i przyswaja hebrajskie zwyczaje, wierzenia, obrzędy, obyczaje. Wchodzi w dzieje rodu, a także narodu. Staje się pełnoprawnym uczestnikiem, „bohaterem” historii żydowskiej. Zawiązuje nierozerwalne więzy solidarności z bliższą i dalszą rodziną. Dziecko rozwija się, wzrasta pod opieką osób starszych, w tym - podeszłych wiekiem. Dom żydowski postrzegany w świetle Biblii można było nazwać „,szkołą, zarówno teorii, jak i praktyki ${ }^{9}$.

${ }^{9}$ Zob. M. Friedman, Tradycja rodzinna $w$ judaizmie, w: Z. J. Kijas (red.), Rodzina $w$ wielkich religiach świata, Kraków 1999, s. 45-58; zob. też R. Bartnicki, Będq dwoje jednym ciałem. Matżeństwo w świetle Nowego Testamentu, Warszawa 2007 (zwłaszcza rozdział I pt. Małżeństwo w judaizmie w poczqutkach ery chrześcijańskiej, s. 7-33). 
Namioty rodzin żydowskich (w czasie ich wędrówki do Ziemi Obiecanej) oraz domy wcześniej niż dwór królewski czy świątynia stanowiły w Izraelu punkt odniesienia dla jednostek oraz dla wspólnot - określonych grup czy rodów. Rodzina zawsze pozostawała u Żydów fundamentem życia narodowego. Społeczność rodzinna, a później także pojedyncza jednostka, stała się (po wejściu do Kanaanu) fundamentem izraelskiego życia wspólnotowego. Rodzina i społeczność rodzinna nabierają w życiu starożytnego Izraela decydującego znaczenia jako struktura wspólnotowa. Dzięki temu kontekst rodzinny jest uważany za solidny fundament w wychowaniu żydowskim we wszystkich czasach. Życie nowych pokoleń realizuje się w ramach rodziny. Głowa rodziny - ojciec, a z nim matka, dzierży w swoich rękach w sposób bezwzględny zadania wychowawcze.

Biblijny Izrael nie powierzył wychowania w ręce osób, które można by określić terminem „urzędników publicznych”. Nie ulokował gwarancji swojego istnienia jako narodu w edukacji publicznej, ale w kulcie wyrażającym szczególną relację narodu z Bogiem. Ta różnica ,istoty” wychowania w porównaniu z wychowaniem określanym jako paidéia w Grecji i w Rzymie stanowi o specyfice wychowania izraelsko-judaistycznego. Wychowanie w Izraelu nie miało celów politycznych - jak w świecie grecko-rzymskim, ale religijne.

Według hebrajskiej tradycji, zakorzenionej głęboko w Biblii, dzieci należą do rodziców. Stanowią one „część” rodziny. Są widzialnym znakiem błogosławieństwa Boga okazywanego rodzicom. To oni powierzają je Bogu wcześniej niż jakiejkolwiek doczesnej - ludzkiej, „ziemskiej” władzy. Ta obecność i wpływ rodziny na wychowanie i wzrost dzieci w biblijnym Izraelu była w pewnym sensie podobna do sytuacji i kontekstu ,pedagogicznego" w starożytnym Egipcie i Mezopotamii.

W Izraelu epoki biblijnej potomstwo było znakiem i dowodem szczególnego Bożego błogosławieństwa, dlatego dzieci były zawsze przyjmowane przez rodziców oraz całą rodzinę z radością i wychowywane z wielką troską, uwagą i zaangażowaniem. Skoro prokreacja była wypełnianiem Bożego nakazu, a więc Prawa, to dzieci nazywane były „darem Pana”. W społeczności biblijnego Izraela szczególnie doceniane było potomstwo płci męskiej ${ }^{10}$.

Dzieci winny okazywać szacunek rodzicom. Sytuują się oni w hierarchii zaraz po Bogu. Najstarsze prawodawstwo potwierdzało zależność dzieci od ojca oraz od matki. W Dekalogu znajduje się przykazanie: „Czcij ojca swego i matkę swoją". Matka była uważana w tradycji biblijnego Izraela za równą ojcu lub nawet pierwszą przed nim. Główną rolę pełnił jednak w ro-

${ }^{10}$ Zob. E. Sakowicz, Co rok to Mesjasz. Dziecko w judaizmie i islamie, „La Salette. Posłaniec Matki Bożej Saletyńskiej” 6 (2009), s. 22n. 
dzinie ojciec. To samo określenie bet-āb odnosi się zarówno do „rodziny”, jak i „domu ojca”. Wobec powyższego dzieci powinny okazywać rodzicom „posłuszeństwo”. Rodzice mają pełne prawo kontrolować życie swych dzieci, za wyjątkiem nielicznych przypadków, w których bezpośrednio interweniuje Prawo ${ }^{11}$.

Rodzice są wzorem pedagogicznym dla dzieci, chociaż w pierwszych latach życia dziecka opieka nad nimi spoczywała prawie wyłącznie na matce. Kobiety nie były nigdy w żydowskiej pedagogicznej praxis wyeliminowane z wychowywania swoich dzieci. Oboje rodziców ponosiło wspólnie odpowiedzialność za formację ich dzieci: religijną, moralną oraz „obywatelską” (tj. odnoszącą się do narodu jako całości - do ,państwa”).

Teksty prawne zamieszczone w Biblii były pisane w rodzaju męskim. Mogłoby to zrodzić przekonanie, że „obowiązek nauczania i nauki odnosił się wyłącznie do mężczyzn; w rzeczywistości nawet w tych czasach nie czyniono różnic między mężczyznami a kobietami i także matki zajmowały się wychowaniem dzieci a córki powinny otrzymać odpowiednie wykształcenie”"12. Księga Przysłów mówi: „Strzeż, synu, ojca wskazówek, nie gardź nauką matki, w sercu je wyryj na zawsze i zawieś sobie na szyi! Gdy idziesz, niech one cię wiodą; czuwają nad tobą, gdy zaśniesz; gdy budzisz się - mówią do ciebie: gdyż lampą jest Prawo, a światłem nauka, drogą do życia wskazówki, nagana" (Prz 6, 20-23).

Wychowanie dzieci było, według Biblii Hebrajskiej, tak ważnym obowiązkiem, że nie mogło zostać powierzone tylko jednemu rodzicowi. Biblia zachęcała młodych ludzi, aby doceniali i stosowali się do napomnień zarówno ojca, jak i matki. Już od pierwszych chwil życia formacja dziecka zakładała nade wszystko odpowiednie wykształcenie. „Kształcić” oznaczało - według Biblii - przede wszystkim zapoznać z tradycjami ojców, historią ich rodziny, wyjaśnić znaczenie sprawowanych obrzędów.

Bóg objawił Abrahamowi swoje postanowienia, aby ten przekazał je „Swoim dzieciom i swojej rodzinie" niejszym prawodawstwie. Księga Powtórzonego Prawa nalegała: „Niech pozostaną w twym sercu te słowa, które ja ci nakazuję. Wpoisz je twoim synom, będziesz o nich mówił przebywając w domu, w czasie podróży, kładąc się spać i wstając ze snu" (Pwt 6, 6-7). I następnie dodawała:

Weźmijcie przeto te słowa do serca i do duszy. Przywiążcie je sobie jako znak na ręku, jako przepaskę na czoła wasze. Nauczcie ich wasze dzieci, powta-

\footnotetext{
11 F. Gioia, dz. cyt., s. 100.

12 Tamże, s. 101.

13 Tamże, s. 102.
} 
rzając je im, gdy przebywacie w domu, gdy idziecie droga, gdy kładziecie się i wstajecie. Napiszesz je na odrzwiach swojego domu i na bramach [miasta], aby się pomnożyły wasze dni i dni waszych dzieci w kraju, który ojcom waszym poprzysiagł dać Jahwe - dni tak długie, jak dni niebios, które są nad ziemią (Pwt 11, 18-21).

Kształcenie winno być - jak przekonywała Biblia Hebrajska - rzeczywistością permanentną, stałą ${ }^{14}$. Było ono zapoczątkowywane przez rodziców:

Przez siedem dni będziesz jadł chleb niekwaszony, a w dniu siódmym będzie dla ciebie święto ku czci Jahwe. Jedynie niekwaszony chleb można jeść w czasie tych siedmiu dni i nie będzie można ujrzeć u ciebie chleba kwaszonego ani nie będzie można ujrzeć żadnego innego kwasu w twoich granicach. W tym dniu będziesz opowiadał synowi swemu: To się czyni ze względu na to, co uczynił Jahwe dla mnie w czasie wyjścia z Egiptu (Wj 13, 6-8).

Ale także same dzieci - jak przekonuje Biblia - mogą chcieć poznać historię swojego narodu:

Gdy syn twój zapyta cię kiedyś: «Co za znaczenie tych przykazań, praw i nakazów, które wam oznajmił nasz Bóg, Jahwe?». Odpowiesz swojemu synowi: «Byliśmy niewolnikami faraona w Egipcie i wyprowadził nas Jahwe z Egiptu mocną ręką. Uczynił na oczach naszych znaki i cuda wielkie i potężne przeciw Egiptowi, faraonowi i całemu jego domowi. Wyprowadził nas stamtąd, by iść z nami i przyprowadzić nas do ziemi, o której przysiagł ojcom naszym, że nam ją da»" (Pwt 6, 20-23).

Ważne było nieustanne wracanie do przeszłości, która stawała się w chwili wspominania teraźniejszością: „Na dawne dni sobie wspomnij, rozważaj lata poprzednich pokoleń, zapytaj ojca, by ci oznajmił, i twoich starców, niech ci powiedzą" (Pwt 32, 7).

Po ukończeniu trzeciego roku życia synowie zaczynali towarzyszyć ojcu poza domem. Córki natomiast pozostawały z matką. Chłopcy zazwyczaj, osiagając wiek młodzieńczy, podejmowali (a tym samym zgodnie z tradycją kontynuowali) zawód ojca, który był przekazywany dziedzicznie. Główną rolę w formacji dziewcząt pełniła matka. Ona wprowadzała swoje córki w wypełnianie domowych obowiązków i zadań, a więc w posługę, służebność na rzecz rodziny.

14 Tamże, s. 103. 
„Nauczanie domowe”, czyli „szkoła rodzinna”, pozostanie u Żydów prototypem każdej innej formy kształcenia. W księgach mądrościowych (nie tylko Izraela, ale także innych starożytnych narodów Bliskiego i Środkowego Wschodu) nauczyciel był nazywany „ojcem”, a uczeń nosił imię „syna”"15. W rodzinie dzieci uczyły się mówić, myśleć, ale także żyć. Przygotowywały się do zdobycia określonej profesji, zawodu, który pozwoli im w perspektywie żyć samodzielnie i odpowiedzialnie.

\section{Codzienna nauka i jej wymiar uniwersalny}

Jak przebiegała edukacja i uczenie się? Każdy Żyd zobligowany był do nieustannego studiowania Prawa. Miał to być jego dożywotni wysiłek i przedsięwzięcie. Bez względu na wiek, status społeczny czy też inne okoliczności każdy miał oddawać się w swoim życiu zgłębianiu Prawa (Ps 1, 1-2).

Obowiązek nieustannej nauki nie ograniczał się do określonej grupy ludzi. Dotyczył różnych warstw społecznych, również władcy. Król winien był zgłębiać Prawo w celu wzbudzania bojaźni Bożej, rozumianej jako pobożność (Pwt 17). Władca winien czuwać nad wiernością Przymierzu ${ }^{16}$.

Władca powinien szczególnie oddawać się studiowaniu Księgi Powtórzonego Prawa, przede wszystkim rozdziałów od 1 do 6 . Fragment ten zawiera tzw. wstępne mowy Mojżesza. Izrael - jak pokazuje ten passus świętej Księgi Żydów - będzie narodem spełniającym misję, zadanie zlecone mu przez Jahwe, jeśli będzie zachowywał Jego przykazania. Król zobowiązany był do nieustannego uczenia się i przestrzegania praw podanych przez Mojżesza. One są natomiast niczym więcej, jak tylko rozwinięciem podstawowego przykazania miłości Boga oraz Dekalogu (Pwt 5, 6-22). Wybrany przez Boga król ma troszczyć się o naród wybrany, walcząc przede wszystkim o zachowanie w nim monoteizmu. Władca winien wystrzegać się zaczepności i agresywności, który to imperatyw wynika z drugiego rozdziału Księgi: Nie grozić Edomitom!; Nie napadać na Moabitów!; Nie zaczepiać Amonitów! Król, za nim cały Izrael, zobligowany został do zachowania przykazań (co jest ostatecznie świadectwem mądrości - Pwt 4, 1-8) oraz do unikania, odwrócenia się od bałwochwalstwa (Pwt 4, 9-24).

Sprawujący rządy ma uświadamiać sobie i przypominać innym wielkość Bożego wybrania, którego dostapił naród żydowski (Pwt 4, 32-38).

15 Tamże, s. 105.

${ }^{16}$ Zob. J. Bagrowicz, Ideat wychowawczy Starego Przymierza (I). Pedagogia Przymierza w Pięcioksięgu, „Paedagogia Christiana” 2 (1998), s. 5-23; tenże, Pedagogia Przymierza w Pięcioksięgu, w: J. Bagrowicz, S. Jankowski, dz. cyt., s. 47-70. 
W życiu swoim powinien kierować się zawsze duchem Dziesięciorga Przykazań. Ma ich przestrzegać, by w tym samym duchu posłuszeństwa Dekalogowi wciąż formować naród powierzony jemu przez samego Boga (Pwt 5). Winien nade wszystko nieustannie pamiętać o miłości Jahwe (Pwt 6). Sam wraz z całym narodem winien kierować się bojaźnią Bożą, która jest wyrazem miłości stworzenia do Stwórcy, znakiem pokory człowieka, czyli prawdy o nim samym. Prawo wraz z królem studiować powinien cały Izrael po to, by następnie się do niego stosować. Odpowiednie nauki władca winien był czerpać z kolejnych fragmentów tej Księgi: z rozdziałów: 11, 13-21 oraz 14, 22. 28. Król to uczeń Tory, Bożego Prawa i porządku.

Wierność Prawu - dzięki powszechnemu weń zaangażowaniu - stała się treścią codziennego życia (Pwt 4, 5-6). Fakt ten wskazuje bardzo wyraźnie na świadomość Żydów, iż wiedza (teoria) i działanie (pragmatyka) są nierozłączne. Nauka Prawa powinna prowadzić do jego realizowania w codziennym życiu. Nauka nie może być celem sama w sobie. Ma być środkiem do osiagnięcia celu. Edukacja żydowska nie tyle przygotowywała teoretycznie do życia, ile była równoznaczna z życiem. Na tym polegała jej specyfika i oryginalność na tle innych systemów edukacyjnych obecnych w narodach ościennych biblijnego Izraela.

Celem edukacji było uczynienie z Izraela „królestwa kapłanów i ludu świętego" (Wj 19,6). Królewskość i świętość narodu wybranego wiązała się z silnymi religijnymi pobudkami, obecnymi w żydowskiej edukacji. Znalazło to wyraz w stwierdzeniu: „Treścią wiedzy jest bojaźń Jahwe, lecz głupcy odrzucą mądrość i karność” (Prz 1,7). Właściwie rozumiany „lęk przed Bogiem” był, według Żydów, początkiem wiedzy. Kształcenie się i w ogóle uczenie się było obowiązkiem każdego religijnego i przestrzegającego Prawa Żyda.

\section{Słuchanie jako droga wychowania i ksztaltowania wiary Izraelitów}

Pedagogika hebrajska skoncentrowana była na zmysłach dziecka. Wychowawcy - rodzice i nauczyciele - „odwoływali się” do oka i ucha dziecka lub ucznia, czyli do jego zdolności widzenia i słuchu ${ }^{17}$. Autor Księgi Przystów zalecał uczniom, by „nachylali” swoje ucho ku mądrości, a serce ku roztropności. „Inteligencja nie polega na osądzaniu, lecz na słuchaniu”. „Ucho bada mowę” - mówił Hiob. „A uszy całego ludu były zwrócone ku Księdze Prawa" - czytamy w Księdze Nehemiasza. Ten, kto staje się głuchy i niemy, powinien obawiać się o swój los - swoją „rzeczywistość”. Uszy

17 F. Gioia, dz. cyt., s. 153. 
i słuch, według autora Księgi Psalmów, są tym, co „,konstytuuje” człowieka, tak jak umiejętność „otwierania ust” i odpowiadania, czyli mowa ludzka.

Człowiek poznaje świat oraz siebie na drodze słuchania. Wartość i jakość życia uzależnione były od słuchania Słowa Bożego, czyli ostatecznie od posłuszeństwa Jemu. Mając na względzie tę prawdę tak interpretowano w Biblii cud manny, którego doświadczyli wędrujący przez pustynię Żydzi: „Utrapił cię. Dał ci odczuć głód, żywił cię manną, której nie znałeś ty, ani twoi ojcowie, bo chciał ci dać poznać, że nie samym chlebem żyje człowiek, ale człowiek żyje wszystkim, co pochodzi z ust Jahwe" (Pwt 8, 3; por. Mt 4, 4). Odrzucenie „słuchania” Boga było, według Biblii Hebrajskiej, odrzuceniem życia.

Idealny „syn”, „uczeń” to ten, którego serce i uszy są uważne; ten, który potrafi słuchać przemawiającego. Salomon w modlitwie inaugurującej jego królowanie prosił Boga o serce gotowe do słuchania bardziej niż o chwałę i honory. Ucho słucha, usta powtarzają to, co usłyszały. Poznane słowo jest odsłuchiwane ponownie we wnętrzu człowieka lub głośno powtarzane do własnego ucha. Jest to droga do tego, by móc „,komunikować się” z Bogiem i ludźmi oraz ubogacać swojego ducha, kształcić się, wychowywać.

\section{Publiczne czytanie świętych tekstów jako metoda edukacji}

Wśród metod edukacji Żydów epoki biblijnej wyjątkowe miejsce zajmowało publiczne czytanie Prawa. Stosowano taką praktykę, aby przybliżyć je jak największej liczbie osób - wszystkim słuchaczom Tory. Adresatami spisanego przez Mojżesza Bożego Prawa byli nie tylko kapłani i starsi Izraela, lecz całe społeczeństwo. Było to obrzędowe czytanie Prawa, będące jednym z ostatnich poleceń Mojżesza. Znalazło to potwierdzenie w Księdze Powtórzonego Prawa:

I napisał Mojżesz to Prawo, dał je kapłanom, synom Lewiego, noszącym Arkę Przymierza Jahwe i wszystkim starszym Izraela. I rozkazał im Mojżesz: «Po upływie siedmiu lat w roku darowania długów, w czasie Święta Namiotów, gdy cały Izrael się zgromadzi, by oglądać oblicze twego Boga, Jahwe, na miejscu, które sobie obierze, będziesz czytał to Prawo do uszu całego Izraela. Zbierz cały naród: mężczyzn, kobiety i dzieci, i cudzoziemców, którzy są w twoich murach, aby słuchając uczyli się bać Jahwe, Boga waszego, przestrzegając pilnie wszystkich słów tego Prawa. Ich synowie, którzy Go jeszcze nie znają, będą słuchać i uczyć się bać waszego Boga, Jahwe, po wszystkie dni, jak długo żyć będziecie w kraju, na przejęcie którego przechodzicie Jordan» (Pwt 31, 9-13). 
Drogę prowadzącą do wiernego przestrzegania Prawa wyznaczało wpierw słuchanie, następnie przyjmowanie nauki i wreszcie tzw. bojaźń Boga, czyli usposobienie znaczone pokorą i gotowością wypełniania Jego nauki ${ }^{18}$.

Podobnie jak Mojżesz, tak i Jozue, podążając śladami tego, któremu Jahwe objawił Swoje Imię, wprowadzał w życie przykazanie publicznej lektury Prawa. Jozue wiedział, że ofiara na górze Ebal i czytanie Prawa było nakazane przez Mojżesza:

Wtedy zbudował Jozue ołtarz dla Jahwe, Boga Izraela, na górze Ebal, jak rozkazał Mojżesz, sługa Jahwe, synom Izraela i jak napisano w księdze Prawa Mojżesza: Ołtarz z kamieni surowych, nie ociosanych żelazem. Na nim złożono dla Jahwe ofiary uwielbienia i pojednania. Jozue napisał tamże na kamieniach tekst Prawa, który Mojżesz spisał dla synów Izraela. Następnie Izrael i jego starsi, przełożeni ludu i sędziowie, zarówno cudzoziemcy, jak i współplemienni, stanęli po obu stronach arki, naprzeciw kapłanów i lewitów, połowa po stronie góry Garizim, a druga połowa po stronie góry Ebal, jak już uprzednio zarządził Mojżesz, sługa Jahwe, aby pobłogosławić lud Izraela. Następnie Jozue odczytał wszystkie słowa Prawa, błogosławieństwo i przekleństwo, wszystko dokładnie, jak napisano w księdze Prawa. Nie opuścił Jozue ani jednego polecenia danego przez Mojżesza, ale odczytał je wobec całego zgromadzenia Izraela, w obecności kobiet, dzieci i cudzoziemców, którzy zamieszkali wśród ludności (Joz 8, 30-35).

Mimo utrwalonego początkowo publicznego czytania Tory, praktyka ta przez szereg lat historii religii biblijnego Izraela była zaniedbywana. Zapomniana została nawet sama Księga Prawa. Duchowa odnowa nastąpiła za panowania króla Jozjasza (621 rok przed Chrystusem). Kapłan Chilkiasz odkrył wówczas „w domu Pana” księgę Prawa, którą ponownie - z rozkazu króla - zaczęto publicznie czytać: „Wtedy król polecił zebrać koło siebie całą starszyznę Judy i Jerozolimy. I wszedł król do świątyni Jahwe, a wraz z nim wszyscy ludzie Judy i wszyscy mieszkańcy Jerozolimy, kapłani i prorocy oraz cały lud od najmniejszych aż do największych. Odczytał dla ich uszu całą treść księgi przymierza, znalezionej w świątyni Jahwe" (4 Krl 23, 1-2).

Religijne odrodzenie, które nastąpiło za króla Jozafata, było bardziej znaczące niż to z czasów Jozjasza. Publiczna lektura i nauczanie Prawa stanowiły bowiem stałą praktykę, a nie, jak za Jozjasza, okazjonalne (jednorazowe)

18 J. Bagrowicz, Wychowanie do stuchania Stowa Bożego, w: J. Bagrowicz, S. Jankowski, dz. cyt., s. 203-218. 
czytanie. Podobny stan ,przebudzenia” religijnego nastąpił w momencie, kiedy Ezdrasz powrócił w 458 roku przed Chrystusem do Jerozolimy z wygnania babilońskiego. Podjął się on dzieła reformy religijnej (Neh 8, 1-8).

Poznawanie Prawa nie było czynnością ,mechaniczną". Nie chodziło tylko o zapamiętanie przykazań Tory, ale o jej zrozumienie. Wprowadzanie Prawa w życie wymagało wcześniejszego zrozumienia go. Publiczne czytanie, jako część trwającej całe życie nauki, nie było celem samym w sobie, ale środkiem do celu - postępowania zgodnego z przykazaniami. Służyło też wypełnieniu przez Żydów zobowiązań wypływających z Przymierza, które Bóg z nimi zawarł.

Reforma przeprowadzona przez Ezdrasza, również w dziedzinie edukacji, polegała na nadaniu nowej wagi dawnym praktykom. Czytanie Prawa przestało być sporadycznym wydarzeniem i stało się cotygodniową czynnością. Prawo było odczytywane w szabat i w dni targowe - w poniedziałki i czwartki, kiedy to liczni mieszkańcy wsi przybywali na handel do Jerozolimy.

W tym czasie pięć Ksiąg Mojżesza podzielonych zostało na fragmenty, tak aby czytanie całego Pięcioksięgu trwało trzy lata. Z czasem tygodniowe sekcje wydłużono, przez co cała Tora odczytywana była w ciąu jednego roku. Tradycja czytania pięciu Ksiag Mojżeszowych istniała przez blisko dwa tysiące lat. Biblijny nakaz czytania Prawa stał się jednym z kamieni węgielnych posługi świątynnej. W tym kontekście czytanie Prawa przekształciło się w niekończące się „,badanie”, tj. naukę Prawa. W momencie, gdy czytanie Prawa wzbogaciło się o lekturę Proroków i Pism, cała Biblia stała się ,księgą pouczającą".

\section{Pedagogiczny wymiar historii i świąt żydowskich oraz uroczystości}

Ważnym narzędziem służącym edukacji była wśród Żydów historia. Pedagogiczny wymiar miało też celebrowanie świąt ${ }^{19}$. Wyznaczały one całoroczny cykl religijnych i ,patriotycznych" uroczystości, w czasie sprawowania których kładziono duży nacisk na historię narodu, jej przypominanie, co więcej - jej uobecnianie. Wzorcowym przykładem edukacyjnego charakteru historii i świąt była Pascha $\left(\right.$ Pesach ${ }^{20}$. W Pięcioksięgu Mojżesza przedstawiona została ona jako Dzień Pamięci: „Dzień ten będzie dla was

19 Na temat świąt w judaizmie współczesnym, ich znaczenia w ogóle oraz ich „funkcji” na drodze życia wyznawców religii mozaistycznej zob. R. Kirsze, H. Schulze, U. Tworuschka, Święta wielkich religii. Kalendarz międzyreligijny. Przegląd synoptyczny, Warszawa 1988, s. $15-32$.

20 Tamże, s. 25n. 
dniem pamiętnym i obchodzić go będziecie jako święto dla uczczenia Jahwe. Po wszystkie pokolenia w tym dniu świętować będziecie na zawsze" (Wj 12, 14).

Żydzi epoki biblijnej wiedzieli, że Pascha ma być celebrowana na wieki (Wj 12, 14. 24), upamiętnia ona bowiem „przejście” narodu z niewoli na wolność. Święto Paschy ma również charakter dziękczynny wobec Boga, który wyzwolił Swój naród „z domu niewoli”. Pascha miała uświadomić Hebrajczyków, iż wszechmogący Bóg zawsze może wyprowadzić człowieka i całą społeczność ludzką z każdej opresji, nawet tej najstraszniejszej.

Święto Paschy, poprzez bogate i rozbudowane ceremonie domowe, dramatyzację i symbolikę, czytelną zarówno dla dorosłych, jak i dla dzieci, przyczyniło się do zachowania pamięci o historii „narodu wybranego" i wierności religijnej tradycji, będącej probierzem żydowskiej tożsamości. Sformułowany w Biblii nakaz spożywania w Paschę chleba niekwaszonego, czyli przaśnego (Wj 12,8$)$, podobnie jak wiele innych rytuałów praktykowanych podczas tego święta, wzbudzał ciekawość dzieci. Pytały one rodziców: „Cóż to za święty zwyczaj?” (Wj 12, 26), czyli „Jaki jest cel tego wyrzeczenia?" Rodzice odpowiadając na pytania dzieci opowiadali im historię wyjścia z Egiptu i mówili o roli, jaką w tym wyzwoleniu odegrał Bóg $(\mathrm{Wj} 12,27)^{21}$.

Pascha stanowiła - według Biblii Hebrajskiej - wielkie święto rodziny. Ojciec, głowa rodziny, przyjmował na siebie kierowanie świętymi obrzędami. Członkowie rodziny wskazywali natomiast symbolicznie na wspólnotę ludu Bożego, będącego w drodze do własnej ojczyzny. Pamięć o niewoli egipskiej i opowieść o nadzwyczajnym uwolnieniu, którego zapragnął Bóg dla swego narodu $(\mathrm{Wj} 12,27 ; 13,8)$ powinny stanowić ważny temat w rozmowach pomiędzy rodzicami a dziećmi. Ceremonie, które upamiętniały cudowne ocalenie, powinny być objaśniane młodym, a wraz z nimi także pojęcia „wolności” i „sprawiedliwości”, które w tych wydarzeniach były wspaniale wysławiane.

Święto Paschy było najbardziej podniosłą i oczekiwaną uroczystością izraelskiego roku liturgicznego. Był to czas, kiedy młodzi nabierali świadomości własnego losu oraz przeznaczenia ich narodu. Autor Księgi Wyjścia pisał:

Gdy cię syn zapyta w przyszłości: Co oznacza ten zwyczaj? - odpowiesz mu: Jahwe ręką mocną wywiódł nas z Egiptu, z domu niewoli. Gdy faraon wzbraniał się uwolnić nas, Jahwe wybił wszystko, co pierworodne w ziemi egipskiej, zarówno pierworodne z ludzi, jak i z bydła, dlatego ofiaruję dla Jahwe męskie

${ }^{21}$ H. R. G. Fried, dz. cyt., s. 12. 
pierwociny łona matki i wykupuję pierworodnego mego syna. Ten obrzęd będzie jakby znak na ręce twojej i jakby przypomnienie między twymi oczyma, że Jahwe potężną ręką wywiódł cię z Egiptu (Wj 13, 14-16).

Innym świętem odgrywającym ważną funkcję pedagogiczną (w tym jako „nośnik” kultury i historii) było Sukkot (Święto Namiotów czy Szałasów) opisane w Księdze Kapłańskiej (23, 33-44). Miało ono charakter pielgrzymkowy. W trakcie celebrowania tego święta Żydzi wspominali trwająca czterdzieści lat wędrówkę Izraela przez pustynię. Wspominano to również poprzez symboliczne czynności - ustawianie namiotów, w których wierni spędzali siedem dni, spożywali w nich posiłki, a także studiowali w nich Biblię. Dzieci natomiast bawiły się w nich. W ustawianie namiotów zwykle była zaangażowana solidarnie cała rodzina. Święto Sukkot stawało się nie tylko symbolem, ale również ,inscenizacją” historycznego wydarzenia. Namiot bywał zbudowany w taki sposób, że konstrukcja jego dachu pozwalała dostrzec gwiazdy. Miało to przypominać młodym i starym Żydom, że namiot (a więc i dom) pełni jedynie rolę tymczasowego mieszkania. Wieczne mieszkanie czeka na Żydów po śmierci ${ }^{22}$.

Funkcję „,cotygodniowej lekcji”, której przedmiotem była historia stworzenia świata i ludzkości, pełnił szabat (Rdz 2, 2-3). Świętowanie szabatu Biblia usankcjonowała przykazaniem Bożym:

Pamiętaj o dniu szabatu, aby go uświęcić. Sześć dni będziesz pracować i wykonywać wszystkie twe prace. Dzień zaś siódmy jest szabatem ku czci twego Boga, Jahwe. Nie możesz przeto w dniu tym wykonywać żadnej pracy, ani ty sam, ani syn twój, ani twój niewolnik, ani twoja niewolnica, ani twoje bydło, ani cudzoziemiec, który mieszka pośród twych bram. Bo w sześciu dniach uczynił Jahwe niebo, ziemię, morze oraz wszystko, co jest w nich, a w siódmym zaś dniu odpoczął. Dlatego pobłogosławił Jahwe dzień szabatu i uznał go za święty (Wj 20, 8-11).

Według Biblii celebrowanie szabatu miało podtrzymać u Żydów świadomość, iż w życiu człowieka najważniejszy jest Bóg Stwórca, który dał mu przykład, jak należy „odpoczywać” po trudzie pracy. Z czasem wprowadzone zostały rozmaite i liczne zwyczaje, które uczyniły z szabatu wydarzenie o charakterze jeszcze bardziej edukacyjnym.

Poznawanie historii, przypominanie jej w wielkie żydowskie święta oraz w dzień szabatu były ,środkiem do realizowania przyszłości”. Nauka

${ }^{22}$ Tamże, s. 13; zob. też. R. Kirsze, H. Schulze, U. Tworuschka, dz. cyt., s. 21 n. 
historii spełniała rolę dynamicznej siły, metody służącej zrozumieniu przeszłości po to, by patrzeć w przyszłość.

Oprócz świąt funkcję pedagogiczną pełniły uroczystości upamiętniające historyczne wydarzenia. Służyło temu stawianie kamiennych monumentów - pomników. Mojżesz nakazał ludowi, żeby ten wzniósł olbrzymie kamienie i na nich, po przybyciu do Ziemi Kanaan, wypisał słowa z Tory: „Na kamieniach wypiszcie wszystkie słowa tego Prawa. Wyryjcie je dobrze!" (Pwt 27, 8). Charakter ,pedagogicznego" pomnika miał też wybudowany przez Jozuego na rozkaz Mojżesza „ołtarz dla Jahwe, Boga Izraela” na Górze Ebal, przy którym odczytane było Prawo (Joz 8, 32).

\section{Znaczenie moralności w wychowaniu i kształceniu młodego pokolenia}

Edukacja winna przede wszystkim polegać na moralnym ćwiczeniu się, na zdobywaniu i udoskonalaniu moralnych predyspozycji człowieka. Skoro Bóg domaga się od człowieka prawego postępowania, to człowiek od najmłodszych lat swojego życia aż do starości winien być „ćwiczony”, „kształcony” w moralności ${ }^{23}$. Według Biblii, każdy religijny człowiek jest człowiekiem moralnym. Niemoralny to po prostu niereligijny. Moralne postępowanie było w religii biblijnego Izraela kryterium religijności. Ćwiczenie się w moralności oraz nauczanie prawd religijnych to fundament edukacji Żydów. Nauczanie moralności to kształtowanie własnego odniesienia do Boga. Izrael jest świętym narodem poprzez ćwiczenie się w moralności. „Materiał” edukacyjny do studium zasad moralności podawała Księga Rodzaju. Przedmiotem wychowania i kształcenia młodego pokolenia w religii biblijnego Izraela były kwestie moralne. Moralność według Biblii ustanowiona została przez Boga dla dobra człowieka. Ma ona go wyzwalać, a nie zniewalać. Bycie moralnym to cel i zarazem wynik kształcenia religijnego.

Nie trzeba być religijnym, aby postępować moralnie, ale według Biblii nie można być religijnym, będąc niemoralnym. Moralność stanowiła u Żydów niewzruszony fundament edukacji. Hebrajczycy byli jednymi z pierwszych ludów, które utożsamiły religię z moralnością. Życie niemoralne nie jest godne miana życia.

Fundamentem, na którym oparte zostało nauczanie religijne, był wspomniany już wcześniej - Dekalog. Cztery spośród Dziesięciu Przykazań dotyczą postępowania człowieka wobec Boga. Sześć kolejnych odnosi się do relacji międzyludzkich. Punktem wyjścia moralnego postępowania była

${ }^{23}$ H. R. G. Fried, dz. cyt., s. 31 n. 
wiara w Boga i cześć Jemu oddawana. Według Biblii Hebrajskiej, ten, który wierzy w Boga i wielbi Go, a jednocześnie ignoruje i poniża innych ludzi jest niemoralny, a więc równocześnie niereligijny.

Obrzędy, w tym składane Bogu ofiary, nie mogą według Biblii Hebrajskiej zastąpić moralności. I chociaż Księga Kapłańska poświęciła wiele miejsca kwestii ofiar składanych Bogu, nie oznacza to, że zapewniają one człowiekowi nieśmiertelność. Ofiara może być postrzegana jedynie jako symbol szczerej intencji ofiarującego. Prorocy zawsze uwrażliwiali naród żydowski, by ofiary przynoszone Bogu nie zastępowały „ducha”, w którym miały być one składane: „Miłości pragnę, nie krwawej ofiary, poznania Boga, nie zaś całopaleń" $(\mathrm{Oz} 6,6)$. Ani celebrowanie świąt, ani odmawianie, tj. śpiewanie Psalmów i wypowiadanie modlitwy, czy wreszcie ofiara nie mogły być celem same w sobie. Były natomiast środkami do osiagnięcia celu - moralnego postępowania.

Silny nacisk kładziony przez Biblię na moralność obejmował wszystkie warstwy społeczne. Nie ma w Piśmie Świętym „klasy wybranej”, jeśli chodzi o moralność. Biedni i bogaci są równi wobec Prawa ustanowionego przez Boga. Również i władca zobowiązany był dostosować się do norm moralnych. Biblia traktuje wszystkich ludzi w sposób jednakowy - wszyscy są przed Jahwe równi. Naród izraelski nie mógł w epoce biblijnej być postrzegany jako posiadający „wrodzoną wyższość”, pomimo że przedstawiany był w Biblii jako „naród wybrany”. Ów wybór obligował Izraela do moralnej doskonałości i do pokory, czyli świadomości prawdy o sobie. Izrael powinien być „świętym narodem” i postępować zgodnie z wolą Jahwe i wiernością Przymierzu.

W moralności kluczową rolę odgrywała, według Biblii Hebrajskiej, wolna wola człowieka. Istota ludzka została nią obdarzona po to, by móc postępować moralnie, tj. bezgrzesznie. Bez wolnej woli moralność pozbawiona jest sensu.

Bardzo ważną „częścią” edukacji moralnej Żyda była nauka etykiety społecznej, czyli nauka dobrych obyczajów i poprawnego zachowania się (biblijny savoir vivre). Przede wszystkim dzieci i młodzież winni nauczyć się respektu wobec osób starszych, które stoją na straży tradycji i którzy przekazują młodemu pokoleniu zasady mądrości życiowej. Szacunek oddawany starszym był jednym z najważniejszych przykazań z zakresu dobrych manier, o których wspomina Księga Kapłańska „Przed siwizną wstaniesz, będziesz szanował oblicze starca, w ten sposób okażesz bojaźń Bożą. Ja jestem Jahwe!" $(19,32)$.

Godnym szacunku byli według religii biblijnego Izraela „obcokrajowcy” mieszkający wśród Żydów: „Jeżeli w waszym kraju osiedli się przybysz, nie będziesz go uciskać. Przybysza, który się osiedlił wśród was, będziecie 
uważać za obywatela. Będziesz go kochał jak siebie samego, bo i wy byliście przybyszami w ziemi egipskiej. Ja jestem Jahwe, Bóg wasz!” (Kpł 19, 33-34). Biblia podaje liczne przykłady gościnności. Przytacza na przykład opowieść o gościnności Abrahama i Lota.

Księgą prawie całkowicie poświęconą manierom i stosunkom międzyludzkim jest wspomniana wcześniej Księga Przysłów. Podaje ona reguły postępowania i zachowania dotyczące różnych okoliczności życia i wielorakich stosunków oraz odniesień międzyludzkich. Podniesiona jest w tej Księdze między innymi kwestia tego, jak powinien właściwie postępować król, handlarz, rolnik, mąż, żona i dziecko. Znajdujemy tam porady, jak traktować przyjaciół, biednych i jak wychowywać dzieci.

\section{Zawody, profesje, umiejętności}

Biblia, będąc głębokim traktatem o relacji Boga do człowieka, jest także księgą wysoce praktyczną. Podanych w niej zostało szereg odnośników do działania człowieka, do jego czynów i do pełnionych zadań ${ }^{24}$. Dzieci poprzez studium Biblii przygotowywały się do podjęcia „roli” życiowej. „Formowane" były do objęcia tradycyjnych funkcji i zadań pełnionych w ich rodach. Podejmowały przygotowania do „dziedziczenia” określonych „profesji” i zadań życiowych. Poprzez przejęcie dziedzictwa danego pokolenia synowie stawali się kapłanami bądź lewitami. Biblia mówi też o artystach i twórcach sztuki. Wskazuje nadto na tańce jako akt uwielbienia Boga, chociaż nie podaje instrukcji, jak posiąść umiejętność tańczenia.

Nie ma w Biblii żadnych oznak oficjalnego nauczania tańca. Mimo to znaleźć można w żydowskiej świętej Księdze szereg odwołań do muzyki i tańca, które były „obecne” zarówno w celebrowaniu uroczystości religijnych, jak i przy innych okazjach. Jubal nazwany został „ojcem” wszystkich „grających na cytrze i na flecie” (Rdz 4, 21). To, jak przebiegała edukacja muzyczna, nie wynika jasno z Biblii. Zgodnie z tym, co mówi Księga Kronik, kapłani otrzymywali specjalne wykształcenie muzyczne (1 Krn 25, 5-7).

Muzyka była ważnym elementem religijnych nabożeństw. Prorocy używali instrumentów muzycznych (harfa, flet, bęben, cytra) i wykonywali pieśni - mogły być one „źródłami” ich natchnienia. Taką grupę proroków spotkał Saul (1 Sm 10,5). To, czy prorocy nauczyli się grać na tych instrumentach w ramach „kształcenia”, które przeszli (o ile takie nauczanie w ogóle istniało) nie wynika jasno z Biblii. Psalmy przypisywane Dawidowi były prawdopodobnie śpiewane przy akompaniamencie instrumentów. Da-

24 Więcej na temat tzw. przygotowania do zawodu zob. F. Gioia, dz. cyt., s. 132-146. 
wid zwany był „śpiewakiem, który spodobał się Izraelowi” (2 Sm 23, 1). Według hebrajskiej tradycji, był on „słodkim śpiewakiem Izraela”. Nie wiadomo, w jaki sposób Dawid zdobył umiejętność muzyczną. Być może nauka muzyki i tańca polegała na obserwacji oraz naśladowaniu dorosłych przez dzieci. Niektóre dzieci (jak właśnie Dawid) mogły mieć wrodzone zamiłowanie do nauki tych sztuk.

W procesie nauczania młodego pokolenia Żydów zwracano wagę na przyszłe zawody i profesje. Według ówczesnych zwyczajów, nie tylko praktykowanych przez biblijny Izrael, ale również wśród ludów i narodów ościennych, ,profesja była dziedziczna”. Król Saul i król Dawid byli pasterzami - jak ich przodkowie - zanim zasiedli na tronie. Również funkcja kapłana i lewity była dziedziczona ${ }^{25}$.

Biblia napomyka też o sztuce. O tym, że sztuka nie kwitła w Izraelu, świadczy opowieść o tym, jak Salomon poprosił Hurama, króla Tyru, o przysłanie mu zdolnego rzemieślnika pracującego w złocie i w srebrze przed rozpoczęciem budowy świątyni (2 Krn 2, 1-17). Dawid wysłał do Salomona odpowiednich rzemieślników, ale przypuszczalnie nie byli oni wystarczająco biegli w swojej profesji, by przewodzić budowie Świątyni ${ }^{26}$.

W Biblii jest mowa także o edukacji fizycznej oraz ,szkoleniu militarnym”. Mojżeszowi dany został rozkaz zorganizowania spisu ludności - „dzieci Izraela", które wyszły z Egiptu. Z tego rozkazu można się dowiedzieć, że od młodych mężczyzn, którzy ukończyli 20 rok życia, oczekiwano dyspozycyjności militarnej. Przygotowanie do wojny obejmowało prawdopodobnie pewien trening fizyczny. Szkolenie to składało się z nauki posługiwania się proca, łukiem i strzała, dzida, mieczem oraz tarcza. Wiele fragmentów z Biblii mówi o zręczności Izraelitów we władaniu procą $(\mathrm{Sdz} 20,16)^{27}$.

Opierając się na świadectwach biblijnych, wnioskować można, że sprawność fizyczna, jak również prawdopodobnie trening wiodący do niej, nie były Izraelowi obce, nawet zanim uległ on wpływom greckim w drugim wieku przed Chrystusem.

\section{Dyscyplina oraz przykłady z życia}

Tematem „metodologicznym” dotyczącym wychowania, a naświetlonym przez Biblię, był problem dyscypliny, czyli sposób odniesienia się do ucznia, sposób postępowania wobec niego oraz egzekwowania wiedzy

\footnotetext{
${ }^{25}$ H. R. G. Fried, dz. cyt., s. 37.

26 Tamże, s. 38.

${ }^{27}$ Tamże, s. 41-43.
} 
i umiejętności, które zdobył. Biblia podaje też czas, w którym powinna zacząc się edukacja dziecka. Winno być ono uczone od samego urodzenia. „Ćwiczenie” dziecka ma zaczynać się wcześnie, tak by w okresie kształtowania się charakteru mogło ono otrzymać i przyswoić najważniejsze zasady dotyczące życia w społeczności Izraela ${ }^{28}$.

W systemie edukacyjnym czasów biblijnych funkcjonowały nagany i kary. Dyscyplina, wymierzanie kar i stosowanie nagród winny być, jak podaje mądrość żydowska, motywowane pozytywnymi, a nie negatywnymi uczuciami. U podstaw stosowania dyscypliny winna być afirmacja, akceptacja ucznia. Miłość i spokój, a nie nienawiść i agresja ma cechować nauczyciela. To wszystko, co on czyni, ma być motywowane miłością.

Bóg w Biblii Hebrajskiej bardzo często przyrównywany był do ojca, który dokonywał „korekty” postępowania swojego syna, swojego dziecka. Przez wymierzanie kary i przez nagradzanie przygotowywał je do prawego życia, w którym najważniejsza miała być miłość.

Biblia Hebrajska podawała wzór metody nauczania, którym było podawanie przykładów z życia. Uczeń miał poznawać zasady moralne na konkretnych przykładach - na konkrecie, a nie na abstrakcji. W świętej Księdze Żydów nie ma tylko suchych, formalnych nakazów: „Czyń to, a tego unikaj!”, „Nie czyń tego a tego!” Najbardziej pedagogicznym, twórczym był konkretny przykład, analiza postępowania konkretnej osoby, która wybierała dobro lub zło. Wzorem dla każdego uczącego się Żyda był Abraham. Dawał on przykład zaufania Bogu, szlachetności. Był bohaterem wiary. Podobnie postawa Lota, charakteryzująca się życzliwością i prawością wobec „posłańców” Boga w kontekście zepsutego ówczesnego „świata”, była godna naśladowania. Święta Księga Żydów podaje szereg przykładów osób, których postępowanie mogłoby być wielką lekcją dla młodego Żyda, szukającego odpowiedzi na egzystencjalne pytania, chcącego poznać zasady postępowania, pragnącego zdobyć mądrość życiową ${ }^{29}$.

\section{Nauczyciele}

Nie ma edukacji bez nauczyciela. Odgrywa on w procesie wychowywania rolę istotna, a wręcz kluczową. Według Biblii, najważniejszym nauczycielem jest sam Bóg (,Wielki jest Bóg w swej wszechmocy, któż takim mistrzem jak On?" - Hi 36, 22). Jahwe objawił Siebie Izraelowi, a poprzez

${ }^{28}$ Tamże, s. 20.

29 Tamże, s. 24; zob. też: W. Chrostowski, Bohaterowie wiary Starego Testamentu, Warszawa 1992. 
Izrael całemu światu, jako Nauczyciel darujący Torę. Bóg jest Nauczycielem, który nie tylko prowadzi konkretną jednostkę jako jej osobisty ,tutor”, ale prowadzi i kieruje losem całego narodu. Jahwe stanowi wzór dla każdego nauczyciela i wychowawcy. Zarówno ojciec rodziny, jak i nauczyciel, któremu ojciec i gmina zleciła wychowywanie dzieci, odzwierciedla, ukazuje swoim postępowaniem prawdę o Bogu - jedynym Nauczycielu Izraela i całej ludzkości ${ }^{30}$.

Wielkimi nauczycielami Żydów są wspominani wcześniej Abraham ${ }^{31}$ oraz Mojżesz ${ }^{32}$. Bóg zlecił Mojżeszowi i pozwolił jemu prowadzić dzieci Izraela: „A teraz, Izraelu, słuchaj praw i nakazów, które uczę was wypełniać, abyście żyli i doszli do posiadania ziemi, którą wam daje Jahwe, Bóg waszych ojców. Nic nie dodacie do tego, co ja wam nakazuję, i nic z tego nie odejmiecie, zachowując nakazy waszego Boga, Jahwe, które na was nakłada" (Pwt 4, 1-2). Mojżesz wychowywał poszczególne jednostki oraz cały naród ${ }^{33}$.

„Pierwszorzędnymi” nauczycielami dla dzieci są wspomniani wcześniej rodzice, przede wszystkim zaś ojciec - głowa rodziny. Najwyższym ich Nauczycielem i wzorcem postępowania jako Wychowawca jest Bóg oraz Mojżesz - ,pedagog woli Bożej”. Bóg zlecił rodzicom wychowywanie dzieci niejako w Jego imieniu. Ich zadaniem jest prowadzenie dzieci prawą drogą. Podobną jak rodzice rolę wychowawczą spełniają dziadkowie ${ }^{34}$.

W Biblii pojecie ,syn” nie zawsze oznaczało syna rodzonego. Bardzo często odnosiło się do tego, który się uczył, do ucznia. Rodzony ojciec w czasach religii biblijnego Izraela „delegował” swoje prerogatywy, uprawnienia wychowawcze nauczycielowi. Z tej właśnie racji określano go jako „ojca”. Pedagogami epoki Biblii Hebrajskiej, czyli „ojcami”, byli kapłani i lewici, a także prorocy i mędrcy.

\section{Podsumowanie}

U podstaw wychowania i kształcenia młodego pokolenia w religii biblijnego Izraela sytuuje się bardzo wyraźnie: monoteizm, świętość, moralność i wolność ludzkiej woli objawiona Żydom przez wszechmogącego Boga.

${ }^{30}$ H. R. G. Fried, dz. cyt. s. 51.

${ }^{31}$ J. Bagrowicz, Pedagogia Patriarchów I. Abraham czlowiek otwarty na nieznane, „Paedagogia Christiana” 4 (1999), s. 68-78.

${ }^{32}$ Tenże, Mojżesz - wychowawca narodu, w: J. Bagrowicz, S. Jankowski, dz. cyt., s. $119-139$.

${ }^{33}$ H. R. G. Fried, dz. cyt., s. 52.

${ }^{34}$ Tamże, s. 53. 
Ważne jest określenie nauczania i uczenia się, czyli słownictwo. W Biblii Hebrajskiej występuje szereg terminów, które określają proces nauczania i uczenia się. Do kwestii edukacji odnoszą się między innymi następujące określenia: ,instruowanie”, ,przestrzeganie”, „trenowanie”, „nakazywanie”, „oznajmianie”, „prowadzenie”.

Żydzi uważają, iż cała Biblia może być postrzegana jako księga dydaktyczna, chociaż formalnie nią nie jest. Niezmiernie ważną pedagogiczną rolę w religii biblijnego Izraela odgrywał dom rodzinny. Dzieci zawsze traktowane były jako dar Boży. Rodzina była pierwszą szkołą, w której poznawały one piękno religii żydowskiej i uczyły się właściwych odniesień do siebie, drugich ludzi i do świata. Szczególna odpowiedzialność spoczywała na ojcu rodziny. Żydzi epoki biblijnej zobowiązani byli do codziennej nauki. Obowiązek nieustannej nauki nie ograniczał się do określonej grupy ludzi. Dotyczył różnych warstw społecznych, również władcy.

Pedagogika hebrajska wśród założeń edukacyjnych podkreślała rolę zmysłów dziecka. Wychowawcy - rodzice i nauczyciele - „odwoływali się” do oka i ucha dziecka lub ucznia, czyli do jego zdolności widzenia i słuchu. Wśród metod edukacji wyjątkowe miejsce zajmowało publiczne czytanie Prawa. Stosowano taką praktykę, aby przybliżyć je jak największej liczbie osób. W procesie edukacji odwoływano się do historii. Pedagogiczny wymiar miało też celebrowanie świąt. Wzorcowym przykładem edukacyjnego charakteru historii i świąt była Pascha (Pesach).

W Biblii podanych zostało szereg odnośników do czynów człowieka oraz pełnionych przez niego zadań (umiejętności, zawodów). Ważny był nadto problem dyscypliny, czyli sposób odniesienia się do ucznia oraz egzekwowanie wiedzy i umiejętności, które zdobył. Ukazywano także uczniom postępowanie i los konkretnych biblijnych postaci, by kształtować ich życiowe postawy. W procesie wychowywania rolę kluczową odgrywał nauczyciel. Według Biblii najważniejszym nauczycielem jest sam Bóg.

W Starym Testamencie znaleźć można także szereg wypowiedzi na temat pedagogiki dorosłych, czyli dzisiejszej andragogiki. Uczniami wobec Boga są zatem nie tylko dzieci i młodzież, ale też dorośli. Edukacja dzieci bez edukacji dorosłych nie ma sensu. To właśnie „zorganizowana” edukacja dorosłych poprzedzała edukację dzieci. Konieczność nieustannego poznawania Biblii obligowała wszystkich bez wyjątku Izraelitów do bycia zawsze uczniem, również w wieku dojrzałym czy starczym. Religijne wychowywanie dzieci rozpoczynało się od wychowywania dorosłych. Dzieci zostaną dobrze wychowane, jeśli ich rodzice będą nieustannie wychowywani. 


\section{The Upbringing of the Young Generation in the Religion of the Biblical Israel (Summary)}

Monotheism, holiness, morality and the freedom of human will, revealed to Jews by the omnipotent God, definitely constitute the cornerstone of the upbringing of the young generation in the religion of the Biblical Israel.

The Hebrew Bible contains a number of terms that describe the process of teaching and learning. Expressions referring to education include "instructing", "cautioning", "training", "prescribing", "declaring" or "guiding".

The family played an extremely important pedagogical function in the religion of Biblical Israel. Children were always regarded as a gift from God. The family was the first school where children learnt about the beauty of the Jewish religion and acquired an adequate approach to themselves, other people and the world. Particular responsibility rested on the father of a family. The Jews of the Biblical era had a duty to study every day. The obligation of continuous study was not limited to a certain category of people; it applied to various social groups, including the ruler. The public reading of the Law (the Torah) held a special place among educational methods. The aim of that practice was to familiarise as many people as possible with the Law. History and celebration of festivals were significant elements of the education process. Passover (Pesach) was a typical example of the educational character of history and religious festivals.

The Bible is a pragmatic book. It contains several references to human actions and tasks (skills, professions). Another important issue was discipline, i.e. the approach to a student and verification of the knowledge and skills he or she had acquired. The stories of Biblical figures were presented to students in order to shape their moral attitudes. The teacher played a key role in the process of upbringing. According to the Bible, God Himself is the most important teacher. 